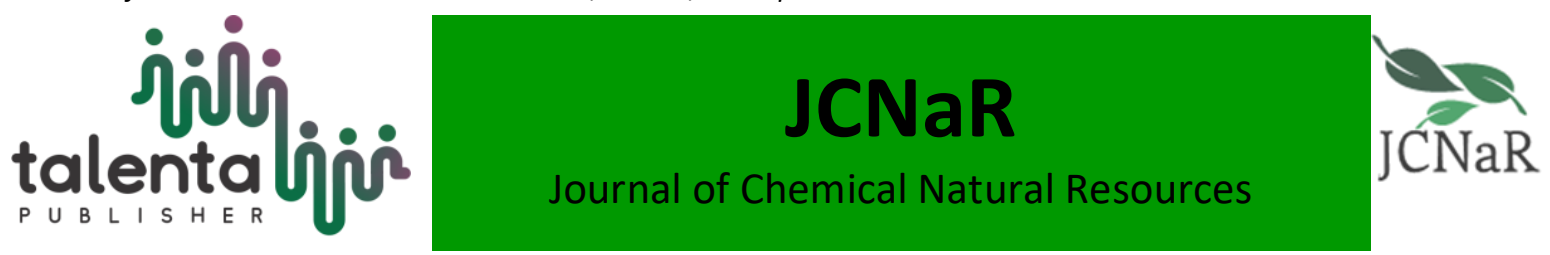

\title{
The Utilization of Carboxymethyl Cellulose (Cmc) from Groundnut (Arachis Hypogaea L) Cellulose as Stabilizer for Cow Milk Yogurt
}

\author{
Firman Sebayang ${ }^{1}$, Rumondang Bulan' ${ }^{2}$, Wike Wahyuni ${ }^{3}$ \\ ${ }^{1}$ Chemistry Department, Faculty of Mathematics and Natural Sciences, Universitas Sumatera Utara \\ Jalan Bioteknologi No. 01 Kampus USU Medan 20155
}

\begin{abstract}
The utilization of carboxymethyl cellulose (CMC) from groundnut (Arachis hypogaea $\mathrm{L}$ ) cellulose as stabilizer for cow milk yogurt has been done in three steps. The first step was $\alpha$-cellulose isolation from groundnut skin powder which was analysed with FTIR. The result was compared to FTIR analysis of commercial cellulose to verify the compound obtained is cellulose. The second step involves alkalization process using isopropanol and $\mathrm{NaOH}$, carboxymethylation process with sodium chloroacetate (NaMCA), neutralization using $\mathrm{CH} 3 \mathrm{COOH} 90 \%$ and ethanol, purification with aquadest and followed by centrifugation and addition of acetone to produce carboxymethyl cellulose. The CMC produced gave positive result in the qualitative anlysis, the FTIR spectrum was similar to commercial CMC and the degree of substitution obtained was 0.71 . The last step is yogurt making process. In this stage, the CMC concentration added was varied from $0-0.5 \%$. Then, the yogurt produced went through quality analysis such as syneresis, $\mathrm{pH}$, viscosity, protein, fat content and organoleptic tests. The best result was obtained at the addition of $0.5 \%$ CMC concentration with $7.69 \%$ and $2.11 \%$ protein and fat content, $\mathrm{pH} 4.6$, viscosity was $1676.01 \times 102 \mathrm{cP}$, low syneresis with $90.66 \%$ stability and 22 days of storage life. Organoleptic result shows that yogurt with $0.3 \% \mathrm{CMC}$ addition gave the best result with distinctive aroma and sourness, and rather thick texture. The panelists preferred such yogurt to others. The quality analysis for yogurt with CMC stabilizer still meets SNI standard. [Use $10 \mathrm{pt}$ Times New Roman for the abstract body with single spacing and $10 \mathrm{pt}$ spacing for the next heading. Left indent is $2 \mathrm{~cm}$ and right indent is $0 \mathrm{~cm}$. Please write abstract paper in English with maximum length is 200 words.]
\end{abstract}

Keyword: Cellulose, CMC, Groundnut skin, Stabilizer, Yogurt

Received 30 July 2019 | Revised 26 August 2019| Accepted 29 August 2019

\section{Introduction}

Yogurt is a result of milk fermentation using lactic acid (generally is the combination between Lactobacillus bulgaricus and Streptococcus thermophilus) with distinct flavor as it contains flavor components. Among the people, yogurt is beneficial for health because it is easily digested in the body and its nutritional content. Yogurt is good for lactose intolerant patients

\footnotetext{
*Corresponding author at: Chemistry Department, Faculty of Mathematics and Natural Sciences, Universitas Sumatera Utara, Medan and Indonesia
} 
who cannot stand lactose due to the lack of lactase enzyme in the colons and as a result they suffer from indigestion. (Marteau, P.R., 2002)

However, there are problems in yogurt's texture stability in which syneresis takes place during the storage. Syneresis is caused by the release of whey in yogurt's body. The hydrogen bond between water molecules (whey) and protein is weakened, then the pores between casein molecules are loosen and leads to water to freely flow (Fennema, 1996). Syneresis in yogurt reduce the quality and it can be observed from the change of yogurt's texture. Moreover, it decreases people's preference to yogurt. Syneresis can be prevented by adding stabilizer like Arabic gum, pectin, starch, carboxymethyl cellulose (CMC), xanthan, gelatin, carrageenan, etc to yogurt.

One of the stabilizers used in this study is CMC which is a derivative of cellulose and a type of modified natural hydrocolloid. CMC acts as stabilizer and obtained from cellulose which is a biomass found abundantly in the Earth with many sources to produce alternative fuel (Tsuji, et al. 2012, Anzai et al, 1984, Bayer, et al, 2004).

One of cellulose sources that can be utilized is groundnut skin. Indonesia produces a big quantity of groundnut because the plant is suitable to be planted in lowland at the height belom $500 \mathrm{~m}$ above sea level (Rukmana, 1993). Groundnut (Arachis hypogaea L.) is one of the main foreign exchange earning crops. It is also a good source of oil, protein and food for people (Ramakrishna, A., 1991 ) Groundnute is the second most important legumes after soybean in Indonesia. However, the skin is rearely utilized in food sectors and disposed right away as waste (Setiawan et al, 2012). According to Irdhawati and friends (2016), groundnut skin has high cellulose content $(63.5 \%)$ followed by lignin $(13.2 \%)$, protein $(8.4 \%)$, water $(9.5 \%)$ ash $(3.6 \%)$ and fats $(1.8 \%)$. Cellulose content in groundnut skin is high enough and has the potential to be processed as cellulose derivatives.

Carboxylmethyl cellulose (CMC) stabilizes yogurt by forming CMC - Protein complex. CMC is anionic where COO- functional group interacts with protein from milk with positive charge, $\mathrm{NH} 3+$ to form a soluble and stable complex (Walocel, 2009). The interaction is illustrated in Figure 1.1.

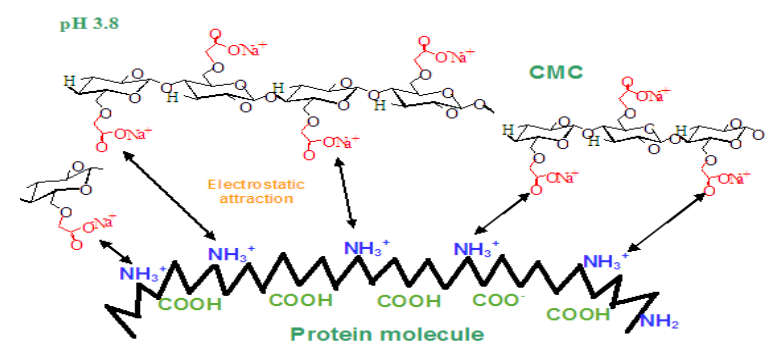

Figure 1.1 CMC interaction in stabilizing yogurt 


\section{Materials and Methods}

\subsection{Tools}

The equipment used in this study was: 80 mesh strainer, analytical balance, beaker glass, hotplate stirrer, oven, thermometer, desicator, incubator, $4000 \mathrm{rpm}$ centrifugator, buretter, erlenmeyer flask, ring stand and clamp, Ostwald viscometer, FTIR equipment set, Kjedahl apparatus, $\mathrm{pH}$ meter, stove, and rotary evaporator.

\subsection{Materials}

The materials used in this study were: groundnut skin, $\mathrm{HNO}_{3} 65 \%, \mathrm{NaNO}_{2}, \mathrm{NaOH}$ pellet, $\mathrm{Na}_{2} \mathrm{SO}_{3}, \mathrm{NaOCl} 15 \%, \mathrm{H}_{2} \mathrm{O}_{2} 30 \%$, isopropanol, sodiu monochloroacetate, methanol, glacial acetic acid, ethanol, acetone, $\mathrm{HCl}$, phenolphthalein indicator, 1-naphtol, $\mathrm{H}_{2} \mathrm{SO}_{4} 98 \%$, standard cellulose, standard CMC, cow milk, granulated sugar, commercial Biokul brand yogurt

\subsection{Groundnut Skin Powder Preparation}

Groundnut skin was cleaned and washed with water. The washing was done with flowing water and air dried at room temperature. Next, it is dried in an oven at $40^{\circ} \mathrm{C}$ for 24 hours. The dried groundnut skin was cut into small pieces and blended to powder with a blender. The powder was sifted with an 80 mesh strainer.

\section{$2.4 \quad \alpha$ - cellulose Isolation from Groundnut Skin}

75 gram of groundnut skin powder was weighed and put into a beaker glass. $1000 \mathrm{ml} \mathrm{HNO}_{3}$ $3.5 \%$ and $10 \mathrm{mg} \mathrm{NaNO}_{2}$ were added and heated at $90^{\circ} \mathrm{C}$ for 2 hours. The mixture was filtered and the residue was washed until the filtrate was neutral. Next, $375 \mathrm{ml} \mathrm{NaOH} 2 \%$ and $375 \mathrm{ml}$ $\mathrm{Na}_{2} \mathrm{SO}_{3} 2 \%$ were added. The mixture was heated at $50^{\circ} \mathrm{C}$ for 1 hour and followed by filtration and residue washing until neutral filtrate was obtained. The residue was whitened with $500 \mathrm{ml}$ of $\mathrm{NaOCl} 1.75 \%$ solution and heated at $70^{\circ} \mathrm{C}$ for 30 minutes. Then the mixture was filtered and the residue was washed until the filtrate is neutral. $500 \mathrm{ml}$ of $\mathrm{NaOH} 17.5 \%$ was added next and it was heated at $80^{\circ} \mathrm{C}$ for 30 minutes and stirred. After that, the mixture was filtered and the residue was washed again until neutral filtrate was obtained. Finally, $250 \mathrm{ml} \mathrm{H} 2 \mathrm{O} 210 \%$ was added and heated at $60^{\circ} \mathrm{C}$ for 15 minutes and stirred. The mixture was filtered and the residue was washed with aquadest until the filtrate is neutral. The residue was dried in the oven at $60^{\circ} \mathrm{C}$ (Ohwoavworhua, 2009).

\subsection{Carboxymethyl Cellulose (CMC) Fabrication}

$5 \mathrm{~g}$ of groundnut skin $\alpha$ - cellulose was weighed and put into a beaker glass. $100 \mathrm{ml}$ of isopropanol was added while stirred and $20 \mathrm{ml} \mathrm{NaOH} 17.5 \%$ was added slowly and stirred for 1 hour at $30 \mathrm{oC}$ and $6 \mathrm{~g}$ of sodium monochloroacetate was added to the mixture. Then, it was put on a water bath and heated at $50^{\circ} \mathrm{C}$ and shook for 2 hours. The pulp mixture formed was soaked in methanol for 1 night. The next day, the mixture was neutralized using $\mathrm{CH} 3 \mathrm{COOH}$ for $90 \%$ 
until $6-8 \mathrm{pH}$ reached and filtered. The final result was washed with $70 \%$ ethanol for 5 times, filtered and dried in the oven at $60^{\circ} \mathrm{C}$ for 24 hours (Bono, et al 2009).

\subsection{Carboxymethyl Cellulose (CMC) Purification}

$5 \mathrm{~g}$ of CMC was added into a beaker glass and dissolved in $100 \mathrm{ml}$ aquadest. The mixture was heated on a hotplate for $80^{\circ} \mathrm{C}$ for 10 minutes and stirred. Next, it was centrifuged for 1 minute at 4000rpm. The precipitate was separated from the solution. The CMC from reprecipitation was dissolved in $100 \mathrm{ml}$ acetone, filtered and wrapped in aluminum foil. Next, it was dried in the oven at $60 \mathrm{oC}$ for 4 hours and stored in a decicator (Hong, 2013).

\subsection{Carboxymethyl Cellulose (CMC) Qualitative Analysis}

$0.5 \mathrm{~g} \mathrm{CMC}$ was weighed and put into a beaker glass and $50 \mathrm{ml}$ aquadest was added. The mixture was heated at $60-70{ }^{\circ} \mathrm{C}$ for 20 minutes. The solution was left cold and used as test solution. The solution is put into test tubes.

Tube I : $1 \mathrm{ml}$ of test solution was diluted with $1 \mathrm{ml}$ aquadest. 5 drops of 1-naphtol was added. The tube was tilted and $2 \mathrm{ml}$ of sulphuric acid was added. The result was observed and recorded. ((+) if the surface turned purplish red) (COEI-1-CMC:2009).

\subsection{Determination of Degree of Substitution}

$4 \mathrm{~g}$ of dried CMC powder was put into a beaker glass and $75 \mathrm{ml}$ of $95 \%$ ethanol was added and stirred for 5 minutes. $5 \mathrm{ml} \mathrm{HNO}_{3} 2 \mathrm{~N}$ was added and the mixture was heated on a hotplate for 10 minutes to boil and stirred in order to remove half of the solution. Next, the mixture was separated to 2 parts by decantation to get liquid phase and solid phase. The liquid phase was removed and the solid phase was washed with $80 \%$ ethanol at $60{ }^{\circ} \mathrm{C}$ for 5 times, followed by washing with a small amount of anhydrous methanol and vacuumed. Next, the precipitate was filtered and dried in the oven at $105{ }^{\circ} \mathrm{C}$ for 3 hours and let cool in a desicator for 30 minutes.

$1 \mathrm{~g}$ of fabricated CMC was weighed and put into a $250 \mathrm{ml}$ Erlenmeyer flask. $100 \mathrm{ml}$ aquadest was added and stirred. Then $25 \mathrm{ml} \mathrm{NaOH} 0.3 \mathrm{~N}$ was added. The mixture was heated to boil for $15-20$ minutes. After the precipitate dissolved, 3 drops of phenolphthalein indicator were added and the solution was titrated by using $0.3 \mathrm{~N} \mathrm{HCl}$ until the color changed from pink to colorless. The titration was repeated twice and the average volume of $\mathrm{HCl}$ used was calculated (Bono, et al 2009).

$\mathrm{A}=(\mathrm{BC}-\mathrm{DE}) / \mathrm{F}$

Degree of substitution $=(0.162 \times \mathrm{x} \quad \mathrm{A}) /(1-(0.058 \times \mathrm{A}))$

\subsection{Yogurt Starter Fabrication}

$300 \mathrm{ml}$ of cow milk was measured and poured into a beaker glass. $15 \%$ of skim milk and $3 \%$ of granulated sugar were added. The mixture was heated at $80{ }^{\circ} \mathrm{C}$ for 10 minutes while it was 
slowly stirred. Next, it is cooled to $45{ }^{\circ} \mathrm{C} .5 \%$ of Commercial yogurt from total mixture volume, Biokul plain, with Lactobacillus bulgaricus, Streptococcus thermophilus, Lactobacillus acidhophillus, dan Bifidobacterium was added and homogenized. Then, the mixture was covered with polyethylene plastic and layered with aluminium foil. Finally, it is incubated at $41^{\circ} \mathrm{C}$ for 6 hours and matured for 3 times (Manurung and friends, 2014).

\subsection{Yogurt Making}

$300 \mathrm{ml}$ of cow milk is poured into a beaker glass and stabilizer was added (CMC) with varied concentration, $0.1 \% ; 0.2 \% ; 0.3 \% ; 0.4 \%$ and $0.5 \%$ and without stabilizer (CMC) addition. Then $15 \%$ of skim milk and $3 \%$ of granulated sugar were added. The mixture was heated at $80^{\circ} \mathrm{C}$ for 10 minutes and stirred slowly. It was cooled to $45^{\circ} \mathrm{C}$ and $5 \%$ of mixture volume was added and homogenized. The homogenous mixture was coverd with with polyethylene plastic and layered with aluminium foil. Then it was incubated at $41^{\circ} \mathrm{C}$ for 6 hours. After yogurt is obtained, the quality analysis was conducted (Manurung and friends, 2014). Quality analysis involves syneresis, pH, viscosity, protein and fat content. The Standard English grammar must be observed. The title of the article should be brief and informative and it should not exceed 12 words. The keywords are written after the abstract, where the manuscript consists of two abstract section, which are conveyed in English and Indonesian language.

\section{Result and Discussion}

\section{1 $\alpha$ - cellulose Isolation from Groundnut Skin Powder}

$\alpha$-cellulose isolation from groundnut skin powder involves delignification, whitening and purification. From those processes, $\alpha$-cellulose produced was white. From 75 gram of groundnut skin powder used, 12.08 gram of pure $\alpha$-cellulose was produce ( $16.10 \%$ yield).

\subsection{Carboxymethyl cellulose (CMC) Fabrication}

$\alpha$-cellulose produced was alkalized using isopropanol and $\mathrm{NaOH} 17.5 \%$, carboxymethylated with sodium monochloroacetate, neutralized using $\mathrm{CH}_{3} \mathrm{COOH} 90 \%$, purified by ethanol $70 \%$ washing and further purification with centrifugation process to produce white CMC powder. From 5 gram of $\alpha$-cellulose used, 5.4 gram CMC produced and from 5 gram CMC used, in the further purification stage produced 3.11 gram purer CMC.

\subsection{Carboxylmethyl Cellulose (CMC) Qualitative Analysis}

CMC produced was analyzed qualitatively by adding other chemicals to observe color change based on some literatures. There are several chemical reactors added, such as:

1. Aquadest + 1-naphtol $+\mathrm{H} 2 \mathrm{SO} 4(\mathrm{p})$ : In literatures, changes from analysis data was stated such as the formation of purplish red ring in the surface. In this study, CMC produced gave positive result with the formation of purplish red ring in the surface as shown in Figure 3.3. 


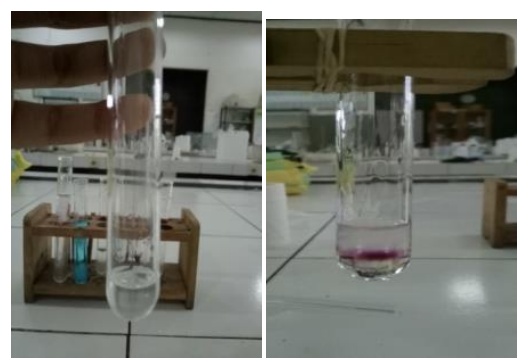

(a)

(b)

Figure 3.3 (a) CMC before aquadest +1 naphtol+ $\mathrm{H} 2 \mathrm{SO} 4(\mathrm{p}$ ) addition (b) $\mathrm{CMC}$ after aquadest +1 naphtol+ H2SO4(p) addition

\subsection{Functional Groups Analysis with FTIR Spectroscopy}

The analysis result for groundnut skin $\alpha$-cellulose, commercial $\alpha$-cellulose, groundnut skin $\mathrm{CMC}$ and commercial CMC functional groups using Fourier Transform Infrared Spectroscopy (FTIR) can be seen in Figure 3.6. Then, the wave numbers for commercial $\alpha$-cellulose, groundnut skin $\alpha$-cellulose, commercial CMC and groundnut skin CMC can be seen in Table 3.1 .

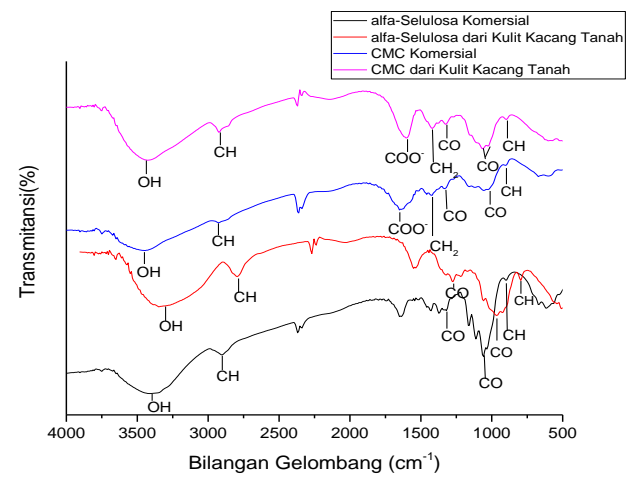

Figure 4.6 commercial $\alpha$ - cellulose FTIR spectrum, groundnut skin $\alpha$ - cellulose, commercial CMC, CMC from groundnut skin. 
Table 3.1. Wave numbers of commercial $\alpha$ - cellulose, groundnut skin $\alpha$-cellulose, commercial $\mathrm{CMC}$, groundnut skin CMC

\begin{tabular}{|c|c|c|c|c|c|}
\hline \multicolumn{4}{|c|}{ Bilangan Gelombang $\left(\mathrm{cm}^{-1}\right)$} & \multirow[b]{2}{*}{$\begin{array}{c}\text { Jenis } \\
\text { Vibrasi }\end{array}$} & \multirow[b]{2}{*}{$\begin{array}{l}\text { Gugus } \\
\text { Fungsi }\end{array}$} \\
\hline $\begin{array}{l}\text { a-Selulosa } \\
\text { Komersial }\end{array}$ & $\begin{array}{c}\boldsymbol{\alpha}-\text { Selulosa } \\
\text { dari kulit } \\
\text { kacang } \\
\text { tanah } \\
\end{array}$ & $\begin{array}{c}\text { CMC } \\
\text { komersial }\end{array}$ & $\begin{array}{c}\text { CMC dari } \\
\text { kulit } \\
\text { kacang } \\
\text { tanah } \\
\end{array}$ & & \\
\hline 3410,15 & 3448,72 & 3448,72 & 3425,58 & Stretching & $\mathrm{O}-\mathrm{H}$ \\
\hline 2900,94 & 2893,22 & 2924,09 & 2924,09 & Stretching & $\mathrm{C}-\mathrm{H}$ \\
\hline- & - & 1635.64 & 1604.77 & Asymmetric & $\mathrm{COO}^{-}$ \\
\hline- & - & 1427,32 & 1419,61 & Bending & $\mathrm{CH}_{2}$ \\
\hline 1319,31 & 1319,31 & 1334,74 & 1327,03 & Stretching & $\mathrm{C}-\mathrm{O}$ \\
\hline 1056,99 & 1064,71 & 1026,13 & $\begin{array}{l}1026,13 \\
1064,71\end{array}$ & Symmetry & $\mathrm{C}-\mathrm{O}$ \\
\hline 894,97 & 894,97 & 902,69 & 894,97 & $\begin{array}{c}\beta- \\
\text { glycoside } \\
\text { linkage }\end{array}$ & $\mathrm{C}-\mathrm{H}$ \\
\hline
\end{tabular}

\subsection{Carboxymethyl Cellulose (CMC) Degree of Substitution Determination}

The degree of substitution of carboxyl and carboxymethyl cellulose functional groups can be determined by potentiometric titration. The degree of substitution in CMC during cellulose alkalization followed by caroxymetilation process using sodium chloroacetate is between 0.4 and 1.3. In this study, the substitution degree obtained from groundnut skin CMC was 0.71. This has proven that the CMC fabricated can dissolve in water with the increase of temperature.

According to Puji L and friends (2013), the degree of substitution for CMC that meets Food Chemical Codex requirements and SNI quality standard is $\geq 0.95$ and $0.7-1.2$. Ferdiansyah M.K and friends (2016) stated that the degree of substitution that meets FAO standard for CMC is $0.2-1.5$. Therefore the CMC produced can be categorized as food grade or safe to be added to any type of food.

\subsection{Yogurt Making}

Yogurt was made with the addition of CMC from groundnut skin cellulose as the stabilizer. In storage, yogurt undergoes syneresis that makes it unstable and therefore does not last long. According to Fennema (1996), stabilizer acts to reduce syneresis and binds with water by increasing protein's hydrophilic properties. Syneresis decrease yogurt's quality.

\subsection{Yogurt's Quality Analysis}

\section{A. $\quad$ Syneresis Test}

Syneresis is an important character to determine yogurt's quality. The faster syneresis is the less good the yogurt's quality is. From the research done, yogurt's storage life and \% stabilization data is shown in Table 3.2. 
Table 3.2 Yogurt's Storage Life and \% Stabilization Data

\begin{tabular}{|c|l|c|c|c|}
\hline \multirow{2}{*}{ No } & \multirow{2}{*}{ Variation } & \multirow{2}{*}{$\begin{array}{c}\text { Storage } \\
\text { life } \\
\end{array}$} & & \multicolumn{2}{|c|}{$\begin{array}{l}\text { \% Stabilization } \\
\text { (Day) }\end{array}$} & $\begin{array}{l}\text { Before } \\
\text { Syneresis }\end{array}$ & $\begin{array}{l}\text { After } \\
\text { Syneresis }\end{array}$ \\
\hline 1 & Control & 3 & $100 \%$ & $66.00 \%$ \\
\hline 2 & CMC 0.1\% & 7 & $100 \%$ & $69,33 \%$ \\
\hline 3 & CMC 0.2\% & 9 & $100 \%$ & $79,66 \%$ \\
\hline 4 & CMC 0.3\% & 14 & $100 \%$ & $85.66 \%$ \\
\hline 5 & CMC 0.4\% & 18 & $100 \%$ & $86.66 \%$ \\
\hline 6 & CMC 0.5\% & 22 & $100 \%$ & $90.66 \%$ \\
\hline
\end{tabular}

From Table 3.2, it can be seen that long storage life with low syneresis and $\%$ stability with high syneresos is in the variation of $0.5 \% \mathrm{CMC}$ concentration. The higher CMC concentration is, the lower syneresis is in yogurt with longer storage life and high \% stability. This is because CMC reduces synersis by preventing interaction between casein and lactic acid by changing the charge of the ions. Casein goes through ion changes from negative to positive as it interacts with $\mathrm{CMC}$ when yogurt's $\mathrm{pH}$ reach isoelectric points. Consequently, casein does not bind lactic acid as they have the same ion charged and casein molecules do not bind with other casein and water molecules surround them to form three dimensions protein structures (Tammime and robinson 1996).

B. $p H$

The determination of yogurt's $\mathrm{pH}$ was done by using $\mathrm{pH}$ meter. The results obtained can be seen in Table 3.3.

Table 3.3 Yogurt's pH Analysis Data

\begin{tabular}{cccc}
\hline \multirow{2}{*}{ No } & Variation & \multicolumn{2}{c}{$\mathrm{pH}$} \\
\cline { 3 - 4 } & & $\begin{array}{c}\text { Before } \\
\text { Syneresis }\end{array}$ & $\begin{array}{c}\text { After } \\
\text { Syneresis }\end{array}$ \\
\hline 1 & Control & 4.24 & 4.13 \\
2 & CMC 0.1\% & 4.29 & 4.15 \\
3 & CMC 0.2\% & 4.36 & 4.18 \\
4 & CMC 0.3\% & 4.56 & 4.20 \\
5 & CMC 0.4\% & 4.57 & 4.46 \\
6 & CMC 0.5\% & 4.60 & 4.50 \\
\hline
\end{tabular}

From Table 3.3, the $\mathrm{pH}$ of yogurt of all variations before and after syneresis meets the standard, which is at $4.0-4.6$. The additional of $\mathrm{CMC}$ affects the $\mathrm{pH}$ before and after syneresis.

Before syneresis, yogurt's $\mathrm{pH}$ increases with the addition of CMC concentration as a result of the fall of total $\mathrm{H}+$ ion with the reduction of total acid. This is caused by the inhibition of bacteria mobility that reduces yogurt's culture activities. According to Hui (1993), stabilizer in high concetration makes lactic acid bacteria activities to be less optimal to transform lactose to become lactic acid and $\mathrm{pH}$ will be high. 
After syneresis, the $\mathrm{pH}$ will fall as during syneresis, fermentation occur and the bacteria which produce lactic acid forms lactic acid. Therefore, yogurt is more acidic and $\mathrm{pH}$ becomes lower. This aligns with the research done by Manab A (2008) who stated that $\mathrm{pH}$ reduction is especially due to the lactic acid produced during lactose fermentation.

$\mathrm{pH}$ reduction after syneresis from before syneresis at varied concentration is not significantly affecting. $\mathrm{pH}$ values still meet the standard. In other words, $\mathrm{CMC}$ is able to maintain the $\mathrm{pH}$.

\section{Viscosity}

Viscosity test was conducted by using Ostwald method. The observation for yogurt's viscosity is in Table 3.4.

Table 3.4 Yogurt's Viscosity Analysis Data

\begin{tabular}{cccc}
\hline & & \multicolumn{2}{c}{ Viscosity $(\mathrm{cP})$} \\
\cline { 3 - 4 } No & Variation & Before Syneresis & After Syneresis \\
\hline 1 & Control & $974.87 \times 10^{2}$ & $1060.16 \times 10^{2}$ \\
2 & CMC 0.1\% & $1168.96 \times 10^{2}$ & $1226.13 \times 10^{2}$ \\
3 & CMC 0.2\% & $1280.78 \times 10^{2}$ & $1353.40 \times 10^{2}$ \\
4 & CMC 0.3\% & $1448.67 \times 10^{2}$ & $1537.89 \times 10^{2}$ \\
5 & CMC 0.4\% & $1563.53 \times 10^{2}$ & $1679.96 \times 10^{2}$ \\
6 & CMC 0.5\% & $1676.01 \times 10^{2}$ & $1722.87 \times 10^{2}$ \\
\hline
\end{tabular}

Table 3.4 shows that before syneresis, the viscosity increases with the addition of CMC. This rises is influenced by the usage of stabilizer in yogurt. The higher the concentration of CMC, the higher the quantity of free water absorbed and binded which leads to stronger gel condition and increases the viscosity. According to Ago et al (2015), CMC has the ability to form threedimension gel matrix that traps water. The formation of gel in CMC is a process to form nets or three-dimension tissue by molecules. The water outside the granules enters the nets and stay unmoved that causes yogurt to be thicker.

After sysneresis, yogurt's viscosity increases. This is an effect of $\mathrm{pH}$ reduction after syneresis at $\mathrm{pH}$ analysis. The fall of $\mathrm{pH}$ increases interaction between protein and solvent that affects hydrodynamic hydration around protein molecules and increases the interaction of casein and improves the size of proteins aggregate. The changes in those interaction increases viscosity (Manab A 2008).

\section{Protein Content}

Protein content test was done by using Kjeldahl equipment. The observation data of yogurt's protein content is presented in Table 3.5. 
Tabel 3.5 Yogurt's Protein Content Analysis Data

\begin{tabular}{llcc}
\hline \multirow{2}{*}{ No } & Variation & \multicolumn{2}{c}{ Protein Content (\%) } \\
\cline { 3 - 4 } & & $\begin{array}{c}\text { Before } \\
\text { Syneresis }\end{array}$ & $\begin{array}{c}\text { After } \\
\text { Syneresis }\end{array}$ \\
\hline 1 & Control & $6.65 \%$ & $3.78 \%$ \\
2 & CMC 0.1\% & $7.12 \%$ & $5.18 \%$ \\
3 & CMC 0.2\% & $7.35 \%$ & $5.41 \%$ \\
4 & CMC 0.3\% & $7.42 \%$ & $5.63 \%$ \\
5 & CMC 0.4\% & $7.51 \%$ & $5.73 \%$ \\
6 & CMC 0.5\% & $7.69 \%$ & $6.04 \%$ \\
\hline
\end{tabular}

From the table above, the protein before and after syneresis of all variations meet with SNI standard. According to SNI 2891:1992, yogurt's protein content is minimum 3.5\%. The addition of CMC influences protein content in yogurt before and after syneresis.

Table 3.5 presented that before syneresis for protein content increases with the addition of CMC concentration. This is caused by CMC to be able to comine with protein functional groups and prevent protein precipitation to take place. This has aligned with Fardiaz (1986) statement that stated CMC can reduce protein precipitation at isoelectric points and increase viscosity that is caused by the combination of carboxyl CMC with positive charge functional groups from protein. Protein content after syneresis is reduced but the reduction of protein content in CMC concentration variation is not very far compared to the control. This has a connection with syneress test. The lower syneresis occurrence is, the higher the protein content is. This happened because the stabilizer reduce syneresis by increasing preotein's hydrophylic characteristic (Fennema, 1996). Syneresis can be defined as the separation of protein when from the surface of gel. Therefore, if yogurt goes through synersis, the protein content decreases. But the existence of stabilizer material, syneresis is low and as a result, protein content does not drop significantly from the initial content.

\section{E. $\quad$ Fat Content}

Fat content was tested by Soxhlet method. The result of yogurt's fat content is displayed in Table 3.6.

Tabel 3.6 Yogurt's Fat Content Analysis Data

\begin{tabular}{clcc}
\hline \multirow{2}{*}{ No } & \multirow{2}{*}{ Variation } & \multicolumn{2}{c}{ Fat Content $(\%)$} \\
\cline { 3 - 4 } & & $\begin{array}{c}\text { Before } \\
\text { Syneresis }\end{array}$ & $\begin{array}{c}\text { After } \\
\text { Syneresis }\end{array}$ \\
\hline 1 & Control & $2.75 \%$ & $3.97 \%$ \\
2 & CMC $0.1 \%$ & $2.61 \%$ & $3.80 \%$ \\
3 & CMC $0.2 \%$ & $2.58 \%$ & $3.75 \%$ \\
4 & CMC $0.3 \%$ & $2.47 \%$ & $3.63 \%$ \\
5 & CMC $0.4 \%$ & $2.38 \%$ & $3.50 \%$ \\
6 & CMC $0.5 \%$ & $2.11 \%$ & $3.22 \%$ \\
\hline
\end{tabular}


The table above shows that yogurt's fat content before and after syneresis of all variations still meet SNI standard except the control after syneresis. According to SNI 2891:1992, maximum fat content for yogurt is $3.8 \%$.

The effect of CMC stabilizer of different concentration before syneresis experiences reduction in fat content with the increase of CMC due to dilution effect. Dilution effect occurs with the content of stabilizer material that reduces nutitional content like fats. Dilution level occur depends on the amoun of stabilizer used (Alakali er al., 2008).

Fat content increases after syneresis because every syneresis process, lactic acid bacteria produce lactic acid which makes yogurt more acidic and coagulates protein. Coagulated proteins have broken molecules configuration of the bonds formed. Therefore the fats binded to the protein were released and escaped from the tissue (Winarti, 2007).

\subsection{Organoleptic Test}

\section{A. Aroma}

The organoleptic test shows that the additional of different CMC concentration does not affect yogurt's aroma.

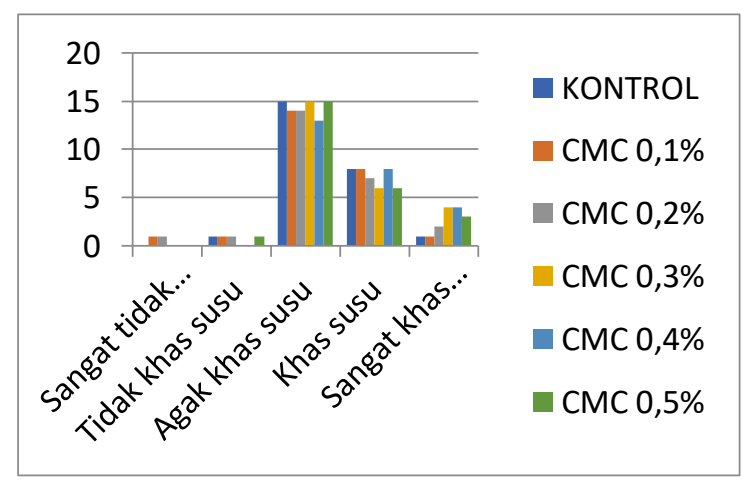

Figure 3.1 Yogurt's aroma and organoleptic value bar diagram

According to Imeson (1992), CMC usage in yogurt making does not affect yogurt's aroma because CMC has no aroma characteristic. CMC is a white ether cellulose molecule. It is solid and odorless.

\section{B. Flavor}

The organoleptic test shows that the additional of different CMC concentration gives significant effect to yogurt's flavor. 


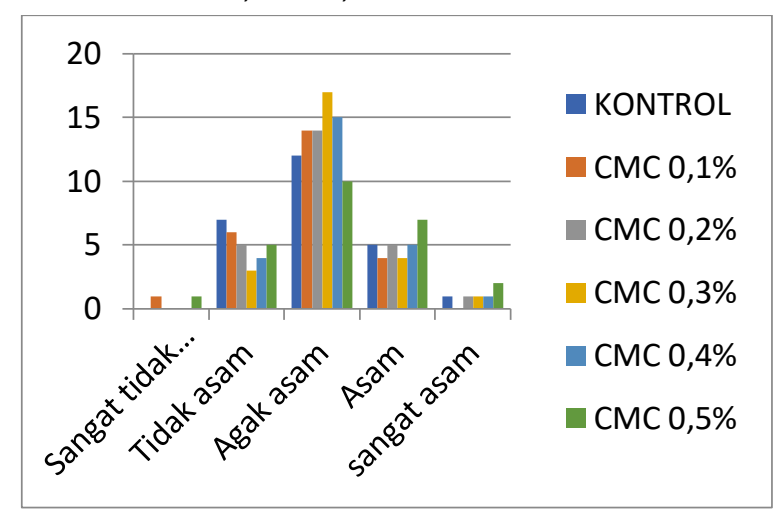

Figure 3.2 Yogurt's flavor and organoleptic value bar diagram

The most preference of yogurt from the panelists is at $0.3 \% \mathrm{CMC}$ addition. The higher the CMC concentration added to yogurt, the less acidic the yogurt is due to low lactic acid produced (Tammime and Robinson, 1989).

\section{C. $\quad$ Texture}

The organoleptic test shows that the additional of different CMC concentration gives significant effect to yogurt's texture.

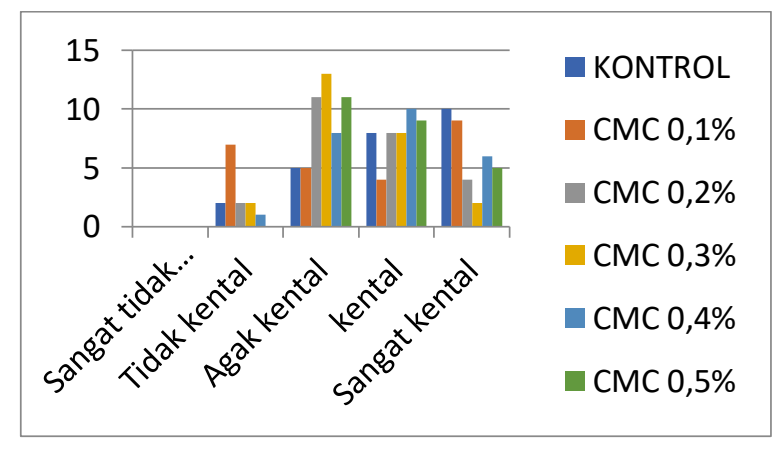

Figure 3.3 Yogurt's texture and organoleptic value bar diagram

$0.3 \% \mathrm{CMC}$ usage produces the highest likeness of yogurt from the panelists because the texture is more uniform.

\section{D. $\quad$ Preference}

Organoleptic test shows that the difference in CMC concentration added gives significant effect to the preference to yogurt. Most panelists prefer yogurt at $0.3 \% \mathrm{CMC}$ concentration.

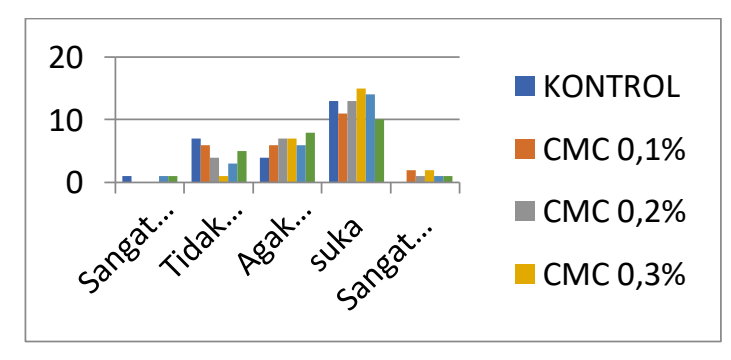

Figure 3.4 Preference to yogurt and organoleptic value bar diagram 


\section{Conclusion}

1. CMC synthesis process was done in 2 ways such as alkalization and carboxymethylation processes. From 5 gram of $\alpha$-cellulose, 5.4 gram CMC was produced. Then 5 gram of CMC powder used, gave 3.11 gram of purer CMC in the next purification process.

2. Carboxymethyl cellulose (CMC) from groundnut skin cellulose influences yogurt's quality. This can be seen in the difference of quality test results on every CMC concentration added to yogurt. From the research, the best result was obtained at the addition of $0.5 \%$ CMC. I

3. Carboxymethyl cellulose (CMC) from groundnut skin cellulose can be used as a stabilizer because it is able to improve yogurt's quality. The lowest syneresis is at CMC $0.5 \%$ addition with $90.66 \%$ stabilization and storage life of 22 days. The section title use $12 \mathrm{pt}$, bold, Times, title case with $6 \mathrm{pt}$ spacing to the body text. The first letter of section title is capitalized and headings are numbered in Arabic numerals. The organization of the manuscript includes Introduction, Methods, Results and Analysis, Conclusion and References. Acknowledgement (if any) is written after Conclusion and before References and not numbered. The use of subheadings is discouraged.

\section{References}

[1] Ago, A.J., Wirawan, dan Santosa, B. 2015. Banana Yogurt Making Of Skin And Feasibility Ambon Need Type And Concentration Effect Stabilizer, Jurnal Agricultural, University Tribuwara Tunggadewi.

[2] Alkali, J.S., Okonkwo, T.M. and Lordye, E.M. 2008. Effect Of Stabilizers On Physico chemical and Sensory Attributes Of hermized Yoghurt, Journal Of Biotechnology, Vol. 7(2) $158-163$.

[3] Anzai, H., Nishizawa, K., Matsuda, K., 1984. Purification and characterization of a cellulase from Dolabella auricularia. J. Biochem. 96, 1381-1390.

[4] Bayer, E.A., Belaich, J.P., Shoham, Y., Lamed, R., 2004. The cellulosomes: multienzyme machines for degradation of plant cell wall polysaccharides. Annu. Rev. Microbiol. 58, 521-554.

[5] Bono, A., Ying, P.H., Yan, F.Y., Muei, C.L., Sarbatly, R, and Krishnaiah. 2009. Synthesis and Characterization of Carboxymethyl Celulose From Palm Kernel Cake, Advances in Natural and Applied Sciences, 3(1) :5-11.

[6] COEI-1-CMC: 2009.OIV-Oeno 366-2009 and CAS 9004-32-4.

[7] Fardiaz, S. 1986. Mikrobiologi Pangan I. Gramedia Pustaka Utama, Jakarta.

[8] Fennema, O.R. 1996. Principles of Food Science Part 1. Food Chemistry Incorporation, New York.

[9] Hong, K.M. 2013. Preparation and Characterization Of Carboxymethyl Cellulose From Sugarcane Bagase, [Essay], Malaysia : university Tunku Abdul Rahman, 1:21-84.

[10] Hui, Y.H. 1993. Dairy Science and Technology Handbook : Principles and Properties. Wiley-VCH, inc. USA.

[11] Imeson, A. 1992. Thickening and Gelling Agents for Food. Blackie Academic \& Profesional, New York. 
[12] Kiros, E., Seifu E., Bultosa, G, and Solomon, W.K. 2016. Effect of Carrot Juice and Stabilizer Microbiological Properties of Yoghurt, Jounal Food Science and Technlogy.

[13] Manurung, D.F., Rusmarilin, H. dan Ridwansyah. 2014. Pengaruh Perbandingan Sari Biji Nangka Dengan Sari Buah Naga Merah Dan Perbandingan Zat Penstabil Terhadap Mutu Yoghurt Buah Naga, Junal Rekayasa dan Pertanian,Vol.2 No. 4.

[14] Marteau, P.R., 2002. Probiotics in clinical conditions, Clinical Reviews in Allergy \& Immunology, Volume 22, Issue 3, pp 255-273.

[15] Ohwoavworhua, F. 2009. Processing Pharmaceutical Grade Microcrystalline Cellulose From Groundnut Husk : Extarction Methods And Chracterization, International Journal of Green Pharmacy.

[16] Ramakrishna, A., Ong, C.K., Reddy, S.L.N., 1991. Integrated weed management for rainfed groundnut. J. Plant Prot. Tropics 8, 111- 119.

[17] Setiawan, A., Andrio, O. dan Coniwanti, P. 2012. Pengaruh Komposisi Pembuatan Biobriket Dari Campuran Kulit Kacang dan Serbuk Gergaji Terhadap Nilai Pembakaran, Jurnal Teknik Kimia. Unsri.

[18] Tsuji, A., Sato, S., Kondo, A., Tominaya K, and Yuasa. K. 2012. Purification and Characterization of Cellulose From North Pasific krill (Euphausia pacifica) Analysis of Cleavage Specificity of The Enzyme, Comparative Biochemistry and Physiology, 163 (1): 324-33.

[19] Tamime, A.Y. and Robinson, R.K. 1985. Yoghurt Science and Techology.Pergaman Press Limited, London

[20] Tsuji, A., Sato, S., Kondo, A., Tominaya K, and Yuasa. K. 2012. Purification and Characterization of Cellulose From North Pasific krill (Euphausia pacifica) Analysis of Cleavage Specificity of The Enzyme, Comparative Biochemistry and Physiology,163 (1): 324-33. 